\title{
THE RELATIONSHIP OF FAMILY ENVIRONMENT, SCHOOL ENVIRONMENT AND THE ROLE OF THE TEACHER IN THE LEARNING PROCESS WITH THE MOTIVATION OF LEARNING IN STUDENTS OF CLASS XI PROGRAMS MACHINING SMK N 2 KARANGANYAR SCHOOL YEAR $2017 / 2018$
}

\author{
Santika Pramutiya Sari ${ }^{1}$, Muhammad Ahyar ${ }^{1}$, Budi Harjanto ${ }^{1}$ \\ ${ }^{1}$ Mechanical Engineering Education, Universitas Sebelas Maret Surakarta \\ Email: santika.pra.sari@gmail.com
}

\begin{tabular}{l} 
KEYWORDS \\
\hline Family Environment \\
School Environment \\
Role of teachers in Learning Process \\
Learning Motivation \\
Mechanical Engineering Education
\end{tabular}

ABSTRACT

\begin{abstract}
The research aims to finding the correlation between family environment, school environment, teachers role, school environment with the motivation of learning of the students in Grade XI of Mechanical Expertise Program of State Vocational High School 2 of Karanganyar. This research is correlational. The population of this research is all of the students as many as 102 in Grade XI of Mechanical Expertise Program of State Vocational High School 2 of Karanganyar. The sample of the study was taken by using the simple random sampling technique and consist of 80 students. The variables of research consisted of three independent variables: family environment, school environment and teacher role in the learning process, and one dependent variable that is learning motivation. Methods of data collection using the questionnaire method. Questionnaire method used to collect data of family environment variable, school environment, the role of the teacher in the learning process and motivation learning. The questionnaire test was conducted on 30 students. Validity and reliability test using SPSS version 21.0. The results showed, there is a significant correlation between two elements.
\end{abstract}

\section{INTRODUCTION}

Properties owned by different students among each other, as well as ways to develop themselves. How to develop the ability of self then depends on the desire of each student-owned or influenced by any personal motivation from each. According to Affine Murtie (2012:63), motivation comes from the word motivation "Rouse". Motivation is the result of a number of processes which are externally or internally from an individual that cause the onset of the attitude of enthusiasm and persistence to carry out certain activities. For a student who's been sitting in my high school/vocational should be more affected by the motivation is internal, because the students already have awareness of the importance of learning for the future. But in reality, there are many students who have not been affected by the internal motivation.

Family environment greatly influence the motivation of learning in students. Family environment is the main thing that has influence on the education of students in the school environment. Family environment that supports children's learning process, will give the spirit so that effect directly or indirectly on the motivation of their learning. Factors that affect the motivation of learning in the family is how parents educate, relationships between 
family members, understanding parents, home atmosphere, economic circumstances and cultural background (Slameto, 2010:60).

Teachers at the school is one of the important factors determining subject matter in educational enhancement. The learning process in schools for the next designed by teachers as an educator to produce learning achievements correspond to the desired. According to Sardiman (2014:144) suggests that the role of the teacher is as follows: as informator, organizers, Director, motivational speaker, initiator, transmitter, facilitator, mediator and evaluator.

According to Dalyono (2009:59), the environment of the school is a State school as a place that also affect the success rate of learning. School environment concerns teacher quality, teaching methods, the suitability of the curriculum with the ability of the child, the State of the facilities or equipment at school, the implementation of the school's code of conduct, and so on, all this presents to affect children's success. Research results show that the school environment influences the performance of teachers and school performance. Likewise against the learning process that concerns the learning motivation of students. Infrastructure contained in the school plays an important role in the learning process. Incomplete infrastructure will make the learning process will be hampered. So is the role of the teacher in the learning process which is used in presenting material to students.

The objectives to be achieved in this research are as follows: to find the relationship between the family environment with learning motivation of students in SMK $\mathrm{N}$ machining program 2 Karanganyar school year $2017 / 2018$, to find a relationship between school environment with learning motivation of students in SMK N machining program 2 Karanganyar school year 2017/2018, to find the relationship between the role of the teacher in the learning process with the motivation of student learning program at SMK N 2 machining Karanganyar and $2017 / 2018$ school year to discover the relationship between family environment, school environment and the role of teachers in the process of learning with student learning motivation program machining in SMK N 2 Karanganyar 2017/2018 school year.

\section{RESEARCH METHODS}

To get the research data that is to be achieved, then the previously done a review immediately. Data collection is carried out by means of a detailed questionnaire spread with objects that have been previously specified. To get data, as supporting required steps as follows :

\section{The Place of Research}

This research was carried out in the CMS State 2 Karanganyar that located on the street. Naval Yos Sudarso Tel. (0271) 494549 Fax. (0271) 6498171, Village Bejen, Karanganyar Regency 57716.

\section{Research Time}

The research starts from February to may 2018 2018. Proceed with the processing and analysis of data and completion in June 2018.

\section{Populations and Samples}

The population in this research is all the students of Class XI Machining Engineering Program at SMK N 2 Karanganyar 2017/2018 school year as much as 104 students consisting of: MA Class 34 students, Grades and grade Students 34 MB MC 36 students. The sample used in this study amounted to 80 students of Class XI Machining Engineering Program of the academic year 2017/2018 at SMK N 2 Karanganyar. The sample used to test the instrument a number of 30 students from the overall population.

\section{Engineering Data Collection}

By giving a set of questions or statements in writing to the respondent to answer it or use a detailed questionnaire/question form. In this study, researchers used a Numerical scale (Numerical Scale). This type of scale is similar to the Semantic Differential scale (Semantic Differential Scale) that contains the statement or question opposing like good-bad, Like anda no, sure-not sure as well as agree-disagree. 


\section{RESULTS AND DISCUSSION}

\section{Analysis Prerequisite Test}

a. Test For Normality

Testing the normality of population and distribution of the data is performed using the residual statistics Kolmogorov-Smirov Z. Data can be said to be normal if a $p$ value $0.05>$, whereas data is said to be normal if not $p$ value $0.05<$

Table 1. The Results of Normality Kolmogorov - Smirnov Z Test

\begin{tabular}{llll}
\hline No & Variabel & $\mathbf{p ~ v a l u e}$ & Result \\
\hline 1. & Family Environment & 0,738 & Normal Distribution \\
\hline 2. & School Environment & 0,508 & Normal Distribution \\
\hline 3. & Teacher's role & 0,837 & Normal Distribution \\
\hline 4. & Motivation & 0,878 & Normal Distribution \\
\hline
\end{tabular}

b. Test Of Linearity

Linearity test used to confirm whether a linear nature between the three variables identified in theory is appropriate. Test of linearity of the respective variables namely variables family environment, school environment and the role of the teacher in the learning process then obtained the conclusion that the data are linear with the significance of 0.05 or 0.000 or $<$ meets the requirements analysis for testing linearity.

c. Multicollinearity Test

This test is conducted to test whether there is a correlation between the independent variables. If there is a correlation then called multicollinearity, while for knowing the symptoms can be detected from the enormity of VIF values (Inflation Variance Factor).

Table 2. Multicollinearity Coefficient

\begin{tabular}{llll}
\hline No & Variabel & Tolerance & VIF \\
\hline 1. & Family Environment & 0,399 & 3,232 \\
\hline 2. & School Environment & 0,562 & 2,524 \\
\hline 3. & Teacher's role & 0,478 & 1,578 \\
\hline
\end{tabular}

The results of Table 2 between variables obtained vakue tolerance over or > value 0.1 and VIF between 1 and 4.

d. Autocorrelation Test

This test is intended to determine whether between bully each independent variable influence each other. This test uses the approach of D-W (Durbin - Watson) with the criteria that if $d$ lies between $d U$ and $(4-d U)$, then the zero hypothesis is accepted, which means it does not happen autocorrelation.

Table 3. Autocorrelation Result

\begin{tabular}{lllll}
\hline $\mathbf{d}$ & $\mathbf{d L}$ & $\mathbf{d U}$ & 4-DI & 4-dU \\
\hline 1,822 & 1,560 & 1,715 & 2,440 & 2,285 \\
\hline
\end{tabular}

Based on the above table 3 Note that $d$ is the value of 1.822 lies between value and value of 1.715 , i.e. $d U$ 4-dU, i.e. 2.285, then it can be concluded that the regression model used, i.e. non-autocorrelation. 
e. Heteroscedasticity Test

This testing aims to test whether a model regression residual variation has the distinction of cases one case observations of others. The test results using SPSS program version 21.0 can be seen in the table below:

Table 4. Heteroscedasticity Result

\begin{tabular}{llll}
\hline No & Variable & Sig. & Summary \\
\hline 1 & Family Environtment & 0,339 & No. Heteroscedasticity \\
\hline 2 & School Environtment & 0,771 & No. Heteroscedasticity \\
\hline 3 & Theacher's role & 0,856 & No. Heteroscedasticity \\
\hline
\end{tabular}

Based on the above table 4 can be known that family environment variables, the school environment and the role of the teacher in the learning process do not occur Heteroscedasticity because the value of $F$ is higher than 0.05 . So it can be stated that the assumptions are met.

f. Hypothesis Testing

The results of the analysis showed that the relationship between family environment and motivation study partially of 0.701 to the value of 0.000 significance $(p<0.05)$. The results of the analysis showed that the relationship between the school environment and the motivation of learning in the child partially of 0.354 significance value of $0.001(p<0.05)$. The results of the analysis showed that the relationship of the school environment and the motivation of learning in the child partially of 0.280 to the value significance of 0.018 $(p<0.05)$. The results of the analysis showed that the correlation coefficient $R$ of double significance by $0.9280 .000(p<0.05)$. The results of the analysis also show the price $F$ count of 157.818 , while the price of table $F(5 \%)$ with $\mathrm{df} 1 \mathrm{df} 2$ and $\$ 3$ of 80 . It turns out that the price $F$ calculate $>F$ table with the significance of $5 \%$ was 2.72 .

\section{The Relationship between the Environments}

The family and the Motivation of learning the results of the data analysis was done by using partial regression analysis obtained correlation $r=0.701 p$-value $=0.000(p<0.05)$, this indicates that there is a significant correlation between family environment den Gan motivation of learning in children. That is, the better the family environment than will the higher learning motivation in children as students. It is also applied vice versa. If the family environment was less useful then the lower grade students learning motivation also XI Machining Engineering Program SMK N 2 Karanganyar.

The implications of the results of the research can be done in several ways. First, the family and its members, especially the parents should be able to create a comfortable home to learn not to interfere with the child when the learning: turn off the television, radio, etc., reduce activities that can interfere with ASI the child to learn. Second, parents always control the progress and development of the children in the study, asking the results of learning activities regularly so that the child is still in supervision and controlled to achieve the purpose of their learning activities. Third, because the family environment is first headline and environment for the children, the parents should be able to create a family environment that is fun, safe, full of compassion, are protected and the main things that can influence child education.

\section{The Relationship between the School Environment and Learning Motivation}

The results of the data analysis were done by using partial regression analysis obtained correlation $r=0.354$ value $p=0.000(p<0.05)$, this indicates that there is a significant correlation between the school environment with the motivation of learning at a NAK. That is, the better the school environment will be the higher learning motivation in children as students. This also applies vice versa, i.e. If the school, not good environment then the lower grade students learning motivation also XI Machining Engineering Program SMK N 2 Karanganyar.

The implications of the results of the research can be done in several ways. First, the citizens of the school environment should better understand how important school environment that can affect the spirit of learning of students with more responsive to notice when there is damage to school facilities that support activities study teaching. Second, the response should be in school facilities adds to the school environment that includes infrastructure, media of learning as well as other matters related to the physical environment, academically and 
socially. Thirdly, schools are expected to provide more rewards to students who Excel so that student learning motivation to Excel increases. Fourth, the school teacher may consider the location and condition of the school. The location and condition of the school are close to the noise and hustle of learning activities can disturb the child. Therefore the layout and floor plan places of learning and teaching activities should be more cared.

\section{The Relationship between the Role of The Teacher In The Learning Process and Learning Motivation}

The results of the data analysis were done by using partial regression analysis obtained correlation $r=0.280$ to the value $p=0.018(p<0.05)$, this indicates that there is a significant correlation between the environmental role of the teacher in the learning process de NGAN motivation of learning in children. That is, the better the role of teachers in the learning process will be the higher learning motivation in children as students. This also applies vice versa, i.e. If family environment less good then the lower grade students learning motivation also XI Machining Engineering Program SMK N 2 Karanganyar.

The role of the teachers here is required, starting from a few things. First, the teacher should provide insights and information that relates to the purpose to conduct a specific study of the science that is being he had learned, and how the benefits and applications of that science in everyday life as well as the development of science in the future. Second, teachers emphasized that learning activities in addition to getting the desired goals of each student also is a requirement that is useful for him in real life. Third, teachers can identify the needs of the students related to the achievement of the learning objectives. Teachers help students sort out whether learning objectives is to get a ranking in its class, is to be the one to educated and learned, is to raise a sense of prestige over the learning achievements is nothing or only for achievment. So teachers can give you the motivation of learning that suits the needs of each student.

\section{The Relationship of Family Environment, School Environment and the Role of The Teacher in The Learning Process and Learning Motivation}

Research results also showed the value of the coefficient of determination (R Square) in multiple linear regression analysis of 0.862 or equal to $86.2 \%$. Note the calculation of the effective contributions and donations are relatively free from each variable bound against. The relative contribution given by family environment variable is of $60 \%$, the relative contribution of school environment variables of $17.62 \%$ and the relative contribution of the variable role of teachers in the learning process is as significant as the Total contribution of 8.60 free variables relative to the variable bound of $100 \%$.

\section{CONCLUTION}

The results of research and analysis that have been outlined in the previous chapter, then a conclusion can be obtained that the family environment had a significant positive relationship with students ' learning motivation of Class XI Machining Engineering Program at SMK N 2 Karanganyar productive family environment with a donation towards the learning motivation of $60 \%$. The school environment has a significant positive relationship with students ' learning motivation of Class XI Machining Engineering Program at SMK N 2 Karanganyar effective school environment with a donation towards the learning motivation of $17.62 \%$. The role of the teacher in the learning process has a significant positive relationship with students ' learning motivation of Class XI Machining Engineering Program at SMK N 2 Karanganyar contributions effective the role of teachers in the learning process terha DAP study motivation of $8.60 \%$. Family environment, school environment, and the role of the teacher in the learning process to simultaneously have a significant positive relationship with the motivation of learning. If the teacher could do that, It will be increasingly higher learning motivation levels will be achieved by students.

\section{REFERENCES}

Dalyono. 2009. Psikologi Pendidikan. Jakarta : Rineka Cipta.

Hasbullah. 2012. Dasar-dasar Ilmu Pendidikan. Jakarta : PT Rajagrafindo Persada.

M. Ngalim Purwanto. 2007. Psikologi Pendidikan. Bandung : PT Remaja Rosdakarya.

Muhaimin, Abdul. 2011. Upaya Guru dalam Motivasi Belajar Siswa Pada Mata Pelajaran IPS. Skripsi Jurusan Pendidikan IPS UIN Syarif Hidayatullah. Jakarta.

Muhibbin Syah. 2011. Psikologi Pendidikan dengan Pendekatan Baru. Bandung : PT Remaja Rosdakarya. Nana Syaodih Sukmadinata. 2011. Landasan Psikologi Proses Pendidikan Remaja Rosdakarya : Bandung. Oemar Hamalik. 2008. Motivasi Kurikulum dan Pembelajaran. Jakarta : Bumi Aksara. 
Rima Rahmawati. 2016. Faktor-faktor yang Mempengaruhi Motivasi Belajar Siswa Kelas X SMA Negeri 1 Piyngan pada Mata Pelajaran Ekonomi Tahun Ajaran 2015/2016. Skripsi. Yogyakarta : UNY.

Sardiman A.M. 2011. Interaksi dan Motivasi Belajar Mengajar. Jakarta : CV Rajawali.

Sardiman. 2016. Interaksi dan Motivasi Belajar Mengajar. Jakarta : Rajawali Pers.

Slameto. 2013. Belajar dan Faktor-faktor yang Mempengaruhi. Rineka Cipta : Jakarta.

Sugihartono, dkk. 2007. Psikologi Pendidikan. Yogyakarta : UNY Press.

Sugiyono. 2012. Metode Penelitian Pendidikan. Alfabeta : Bandung.

Suharsimi Arikunto. 2009. Dasar-dasar Evalasi Pendidikan. Jakarta : Bumi Aksara.

Suharsimi Arikunto. 2010. Prosedur Penelitian : Suatuu Pendekatan Praktek. Jakarta : Bumi Aksara.

Winkel. 2009. Psikologi Pengajaran. Media Abadi : Yogyakarta.

Sumber internet :

Al Qomariyatin. 2013. Pengaruh Kelengkapan Fasilitas Belajar dan Penggunaan Metode Pembelajaran Terhadap Motivasi Belajar Siswa Kelas XI IPS SMA Negeri 1 Kartasura Tahun Ajaran 2012/2013. Jurnal Pendidikan (Online)http://eprints.ums.ac.id/26688/14/JURNAL PUBLIKASI.pdf (Diakses 28 Maret 2018)

A. Fatih Syuhud. Meningkatkan Motivasi Belajar.http://eprints.walisongo.ac.id/1217/5/4101103_Bab2.pdf. (Diakses pada 28 Maret 2018)

Sahid Raharjo. Teori Sampel dan Sampling Penelitian.http://www.konsistensi.com/2013/04/teori-sampel-dansampling-penelitian.html (Diakses pada 28 Maret 2018)

Tu'. 2004. Pengertian Prestasi Belajar. http://blog.tp.ac.id/pengertianprestasi-belajar. (Diunduh 31 Maret 2018) 